\title{
Varicella Zoster Antibodies after Herpes Zoster, Varicella and Multiple Sclerosis
}

\author{
R.T. Ross, L.E. Nicolle, M.R. Dawood, Mary Cheang and C. Feschuk
}

\begin{abstract}
Background: We previously showed that Manitoba Hutterites seek physician care for varicella zoster virus infection significantly less than non-Hutterites. The current study was undertaken to measure varicella zoster virus seroprevalence for Hutterite and non-Hutterite controls. Methods: Blood was obtained from 315 Hutterites and 259 similar age and sex controls at the time of blood donations to The Canadian Red Cross Society. The controls were from the same or a contiguous postal code area and were collected at the same time as the Hutterite samples. The immune status of the specimens was determined by the ELISA method (enzyme linked immunosorbent assay). Results: Twenty-eight per cent of 315 Hutterites had no immunity and an additional $25 \%$ had only marginal immunity. Among the 259 controls, $10 \%$ had no immunity and an additional $10 \%$ had only marginal immunity $(\mathrm{p}<.0001)$. Conclusions: Manitoba Hutterites have significantly decreased seroprevalence to varicella zoster virus infection. This study of serum varicella zoster virus antibodies verifies a previous population based study that demonstrated the relative rarity of varicella and herpes zoster among a particular population group.
\end{abstract}

RÉSUMÉ: Anticorps contre l'herpesvirus varicellae après le zona, la varicelle et la sclérose en plaques. Introduction: Nous avons montré antérieurement que les Hutterites du Manitoba ont recours à des soins médicaux pour l'infection par l'herpesvirus varicellae (HVV) beaucoup moins souvent que les non-Hutterites. Nous avons entrepris cette étude pour mesurer la séroprévalence du HVV chez les Hutterites et chez des contrôles nonHutterites. Méthodes: Nous avons prélevé du sang chez 315 Hutterites et chez 259 contrôles appariés pour l'âge et le sexe au moment de dons de sang à la Croix Rouge du Canada. Les contrôles provenaient d'une région ayant le même code postal ou d'une région contiguë et les prélèvements ont été obtenus en même temps que ceux faits chez les Hutterites. Le statut immunologique des échantillons a été déterminé par ELISA (dosage immuno-enzymatique sur phase solide). Résultats: Vingt-huit pourcent des 315 Hutterites n'avaient pas d'immunité et $25 \%$ n'avaient qu'une faible immunité. Parmi les 259 contrôles, $10 \%$ avaient aucune immunité et un autre $10 \%$ n'avaient qu'une faible immunitê $(\mathrm{p}<0001)$. Conclusions: Les Hutterites du Manitoba ont une séroprévalence significativement plus basse pour l'infection par le HVV. Cette étude des anticorps contre le HVV confirme une étude de population antérieure qui avait démontré la rareté relative de la varicelle et du zona dans une population particulière.

Can. J. Neurol. Sci. 1997; 24: 137-139

In a previous study of 5601 Hutterite Brethren we documented that multiple sclerosis was rare compared to age and sex matched non-Hutterite neighbours who served as controls. It was also found that varicella and herpes zoster occurred significantly less often in the Hutterite population. ${ }^{1}$

There is a correlation between the occurrence of multiple sclerosis (MS) and varicella (V) in North America ${ }^{2}$ and worldwide. ${ }^{3-5}$ Varicella thrives in many countries that are high risk for $\mathrm{MS}^{4,5}$ and is rare, often an adult disease, and of low contagion where MS is rare..$^{6,7}$ In West Bengal, with allegedly rare MS, only $20 \%$ of children have had varicella by age 10 and the mean age of occurrence was 24 years. ${ }^{7}$ A notable exception to this relationship is Japan where $\mathrm{V}$ is common and MS is relatively rare $\left(<5\right.$ per 100,000). ${ }^{8,9}$

The current study reports the varicella zoster virus antibody levels in a group of Hutterites and controls.

\section{MeThodS}

The protocol was approved by the University of Manitoba Faculty Committee for the Use of Human Subjects in Research. Hutterites are regular and conscientious blood donors who consider this a community obligation. The Elder of each of the 82 Colonies was asked for permission to take $5 \mathrm{ml}$ of blood at each donation. At the donor clinic each Hutterite was age and sex matched to a non-Hutterite and all gave written consent to participation after discussion of the study purpose. The Hutterites

From the Section of Neurology (R.T.R.), Infectious Disease (L.E.N.), and Biostatistical Consulting Unit (M.C.), University of Manitoba, Winnipeg; The Cadham Provincial Laboratory (M.R.D.), and The Canadian Red Cross Society, Blood Services, Manitoba Division (C.F.).

RECEIVED AUGUST 23, 1996. ACCEPTED IN FINAL FORM NOVEMBER 7, 1996. Reprint requests to: R.T. Ross, M.D., GF535-820 Sherbrook Street, Winnipeg, Manitoba R3A 1 R9 
came from 51 different colonies and the controls were resident in the same or a contiguous postal code area.

All blood specimens were kept refrigerated and were transported to the Cadham Provincial Laboratory the day after collection. Varicella antibodies were measured by the enzyme linked immunosorbent assay (ELISA) method. The Enzygnost AntiVZV IgG, Hoechst-Bering kit was used. *Testing was aimed at determining sero-immunity and not simple seropositivity. The antibody levels were analyzed in a three-way analysis of vari- ance (ANOVA). The three effects studied were Hutterites/nonHutterites, six age groups (decades), and sex. We also designated the antibody levels as no or marginal immunity, i.e., ELISA $<0.6$ as specified by Hoechst-Bering and those with immunity, i.e., ELISA > 0.6. The Mantel-Haenszel stratified analysis was used adjusting for age and stratifying by sex. The likelihood of a Hutterite to have VZV immunity was contrasted with age-sex matched non-Hutterites. Ninety-five per cent Confidence Interval was also estimated for the odds ratio.
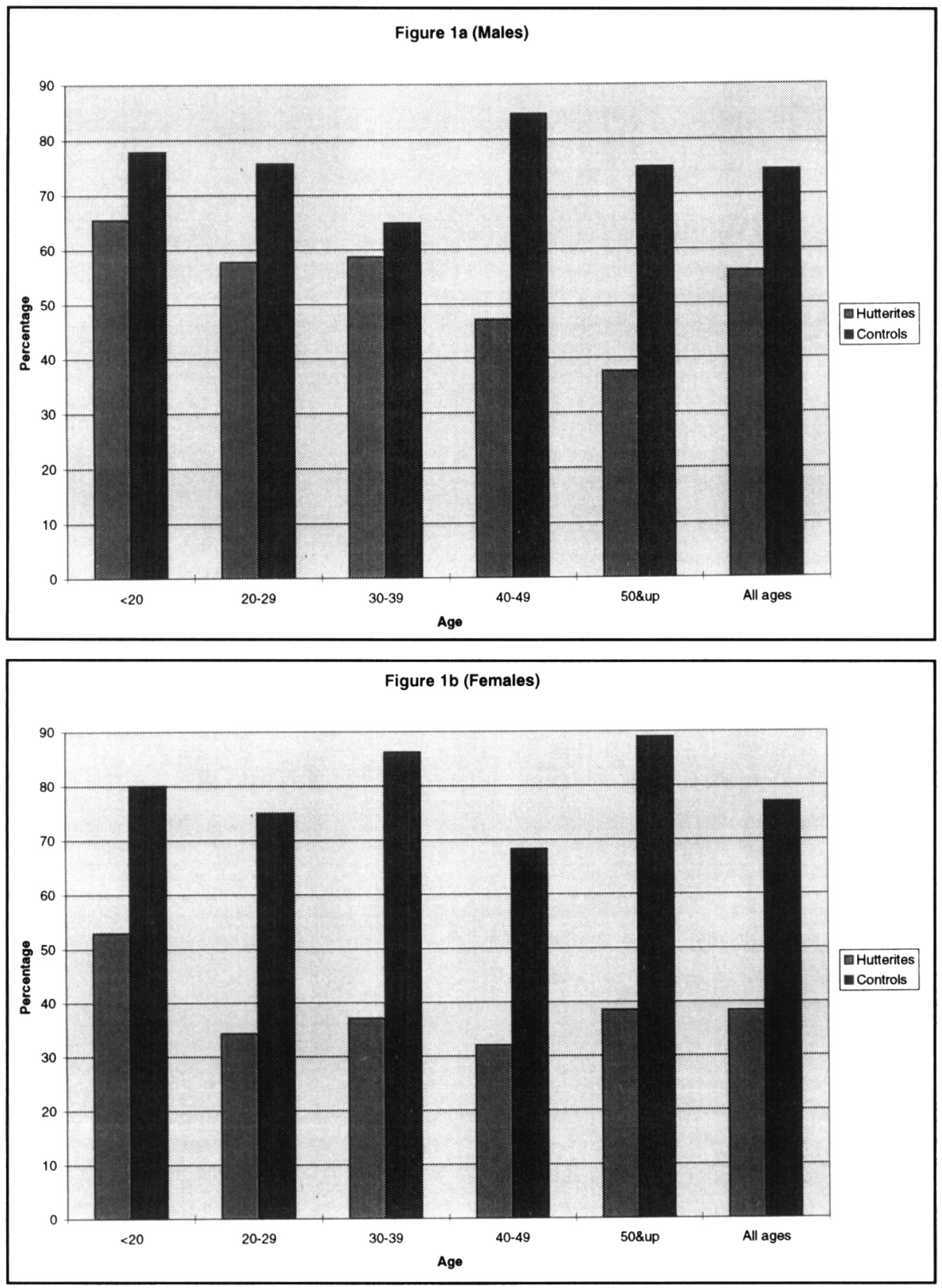

Figure 1: Percentage of all Hutterites and controls with varicella zoster virus seropositive immunity (i.e., antibody level > .059 ELISA): $a=$ males

$b=$ females

\footnotetext{
* Provided by Behringwerk AG, D-35001 Marburg, Germany.
} 


\section{Results}

Three hundred and fifteen Hutterites from 51 colonies provided blood specimens for testing at five mobile blood donor clinics. This represents $5.5 \%$ of all Hutterites in Manitoba. Two hundred and fifty-nine non-Hutterites, at the same donor clinics, who were of the same age and sex, served as controls for the Hutterites. The ABO blood groups were randomly distributed between the Hutterites and the controls. Half of each group was male. Ages ranged from 18 to 69 with the greatest proportion being 20 to 39 years old ( $66 \%$ of the entire group). The odds ratio for immunity between males and females were heterogeneous (Breslow-Day test $p=0.021$ ) but homogeneous by age groups $(\mathrm{p}=0.80)$. Age-adjusted female odds-ratio for immunity was $0.17,95 \% \mathrm{CI}(0.10-0.29)$, $\mathrm{p}<.001$. Male odds-ratio was 0.41 , $95 \%$ CI $(0.24-0.68) \mathrm{p}<.001$ (Figure 1a, 1b). Twenty-eight per cent of the Hutterites had no varicella immunity and an additional $25 \%$ had only marginal immunity. Among the controls $10 \%$ had no immunity and an additional $10 \%$ had only marginal immunity. The reduced seroprevalence among Hutterites is homogeneous across all ages and the differences between Hutterites and controls is significant at all ages.

\section{Discussion}

Hutterites are Anabaptists of Tyrolean origin, highly inbred with large families, a communal lifestyle and well documented pedigrees. They have little MS. ${ }^{1}$ There were 5601 Hutterites at the time of this study living in 82 colonies in Manitoba. They can be identified by their postal codes, the word "Colony" in their addresses, and the presence of one of their exclusive 22 family names.

A previous study of the 5601 Manitoba Hutterites over seven years found a highly significant lower occurrence of varicella, herpes zoster, and multiple sclerosis among them compared to an equal number of their neighbours who served as controls. ${ }^{1}$ The difference in the rate of varicella is unlikely to be due to lack of exposure. The Hutterites are not isolated. The men are highly skilled mechanics, builders, husbandmen and artisans, and travel widely throughout the Province. Also, the average colony has a constant stream of visitors, school tours, bus tours, salespeople, and random tourists. Hutterite families are often seen in shopping malls, hospitals, and other public places. The observations from the present study suggest Hutterites less frequently show humoural antibody evidence of VZV infection in all age groups.

The VZV serum antibody levels in the present study are consistent with the paucity of varicella and herpes zoster revealed in the previous population based study.' That study showed the Hutterites, over the age of 30 , used the government sponsored health care system much more frequently than the controls ( $p<$ $.001)$. If lack of exposure is not the explanation for the observed differences in seroprevalence, an alternative mechanism might be that Hutterites are less likely to respond to infection with humoural antibody mechanisms and manifest prior infection via cell mediated immunity.

In summary, this study documents the significant reduction of antibodies to varicella zoster virus among the Manitoba Hutterite population relative to the non-Hutterite population. This is consistent with the previously reported clinical paucity of chicken-pox and herpes zoster among the Hutterites. The significance and association of these observations with the relative rarity of multiple sclerosis among the Hutterites remains unknown.

\section{ACKNOWLEDGEMENT}

The authors thank Gail Landry for assistance in literature searches, manuscript preparation, and administration of funds. The authors are also extremely grateful to all the Hutterite Brethren Families of Manitoba who so willingly cooperated in this study. Funded by Merck Frosst Canada, Inc.

\section{REFERENCES}

1. Ross RT, Nicolle LE, Cheang M. Varicella zoster virus and multiple sclerosis in a Hutterite population. J Clin Epidemiol 1995; 48(II): $1319-1324$.

2. Ross RT, Cheang M. Geographic similarities between varicella and multiple sclerosis: an hypothesis on the environmental factor of multiple sclerosis. J Clin Epidemiol 1995; 48(6): 731-737.

3. Martyn $\mathrm{CN}$. The epidemiology of multiple sclerosis. In: Matthews WB, Compston A, Allen IV, Martyn CN, eds. McAlpine's Multiple Sclerosis, 2nd edition, Edinburgh: Churchill Livingstone, 199I; Section 1: $3-40$.

4. Gordon JE, Ingalls Th. Chickenpox: an epidemiological review. Am J Med Sci 1962; 244: 363-389.

5. Preblud SR, D'Angelo LJ. Chicken-pox in the United States 19721977. From the Center for Disease Control. J Inf Dis 1979; 140(2): 257-259.

6. Maretic Z, Cooray MPM. Comparisons between chickenpox in a tropical and a European country. J Trop Med \& Hyg 1963; 66: 311-315.

7. Sinha D. Chicken-pox - a disease predominantly affecting adults in rural West Bengal, India. Int J of Epidemiol 1976; 5(4): 367-374.

8. Takahashi M. Herpes Viridae: varicella-zoster virus. In: Lennette EG, Holonen P, Murphy FA, eds. Laboratory Diagnosis of Infectious Diseases: Principles and Practice. Vol II. Viral, Rickettsial and Chlamydial Diseases. New York: Springer Verlag; 1988; 26l-283.

9. Kuroiwa $\mathrm{Y}$, Igata $\mathrm{A}$, Itahara $\mathrm{K}$, et al. Nation-wide survey of multiple sclerosis in Japan. Neurology 1975; 25: 845-851. 